


\title{
Regional Trends in Water-Well Drilling in the United States
}

\author{
By Gerald Meyer and G. G. Wyrick
}

\section{GEOLOGICAL SURVEY CIRCULAR 533}

A description of relations between water-well drilling and regional changes in economy and development, population growth and shifts, changes in irrigation practice, and natural phenomena such as earthquakes and droughts

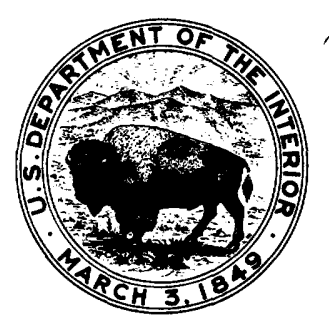


United States Department of the Interior STEWART L. UDALL, Secretary

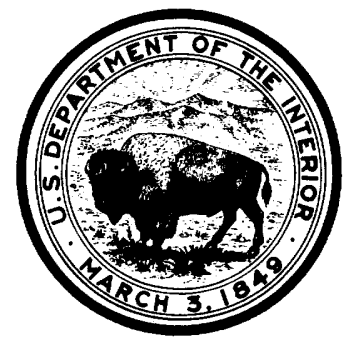

Geological Survey

William T. Pecora, Director

父 


\section{CONTENTS}

Page Page

Abstract.......... 1 National trends in well drilling 1 ........ 3

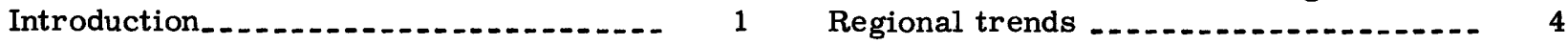

National annual investment in water Summary

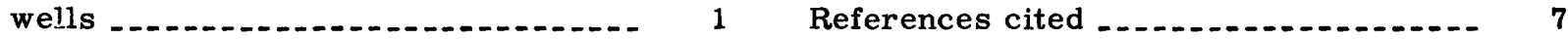

\section{ILLUSTRATIONS}

Figure 1. Map showing changes in well-drilling activity, 1960-64

2. Map showing number of water wells drilled in 1964, by State . .

3. Graph showing number of water wells drilled in the United States between 1900

and 1965 and relation to major events in American history.

\section{TABLES}

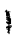

Table 1. Estimated number of water wells drilled in the United States, by State Page

2. Regional trends in water-well construction in the United States, 1960-64 


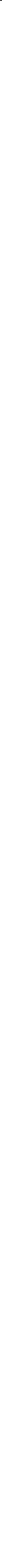




\title{
Regional Trends in Water-Well Drilling in the United States
}

\author{
By Gerald Meyer and G. G. Wyrick
}

ABSTRACT

The well-drilling industry is one index of the importance of ground water to our national economy. National investment in water wells totals about one-half to three-quarter billion dollars annually. The overall industry is currently experiencing a sharp upswing in drilling activity, but activity varies from region to region. Regional changes in drilling activity are determined by regional changes in economy and development, population growth and shifts, changes in irrigation practice, and even natural phenomena such as earthquakes and droughts.

Analysis of estimates of the number of water wells drilled in the United States during the period 1960-64 reveals national and regional trends in water-well construction. Approximately 435,700 wells were drilled in 1964_an average of 1,700 well starts each working day. For the Nation as a whole, the net change between 1960 and 1964 was an increase of 14 percent in drilling activity.

\section{INTRODUCTION}

Information on well-drilling activity furnished by district offices of the U.S. Geological Survey's Water Resources Division, State engineers, State Geological Surveys, and other State water agencies permit realistic estimates of the number of water wells drilled in the United States during the period 196064. The tally of wells drilled in 1960 and 1964 , by State, is given in table 1. Analysis of the data reveals national and regional trends in water-well construction (fig. 1, table 2) and intensity of drilling throughout the Nation (fig. 2).

The well-drilling industry is one index of the importance of ground water to our national economy. Practically all the rural population of the United States and sizeable segments of its urban population, industry, and agriculture rely upon the ground-water reservoirs as a source of supply. Water wells have been a significant factor in the habitation of rural and suburban areas, expansion of the practice of irrigation, and decentralization of industry.
An estimated 10 to 15 million wells are in existence today. In 1950, ground-water use totaled 30 to $35 \mathrm{bgd}$ (billion gallons per day) (MacKichan, 1951; McGuinness, 1963, p. 83); in 1960, it totaled about 46 bgd (MacKichan and Kammerer, 1961). These estimated values indicate that ground-water use increased 30 to 50 percent between 1950 and 1960. On the basis of this 10-year rate of increase, withdrawals in 1965 of between 53 and $69 \mathrm{bgd}$ are indicated. Projection of this rate of increase to 1980,15 years hence, indicates ground-water use of about 80 to $100 \mathrm{bgd}$. In the past 15 years, ground water has supplied between onefifth and one-sixth of the Nation's total withdrawal use $^{1}$ of water. Alfred Loehnberg (in Ackerman and others, 1960, p. 22) has predicted that the ratio of ground-water to surface-water withdrawal might increase to $1: 2$ or even $1: 1$ in the next 20 to 50 years. If so, the total ground-water use in 1980 might be considerably greater than the projected range just given. Although some hydrologists consider these predicted rates of increase in ground-water use too high, there is general agreement that ground-water use will continue to increase.

\section{NATIONAL ANNUAL INVESTMENT IN WATER WELLS}

Approximately 435,700 wells were drilled in 1964-an average of about 1,700 well starts each working day. The bulk of ground water used for domestic, irrigation, industrial, and public supply is withdrawn through wells. Well drilling is a sizeable industry: according to the editor of the "Water Well Journal," an estimated 13,000 contractors operate about 27,000 drilling machines.

\footnotetext{
1owithdrawal use" is defined as water diverted from its place of occurrence for use.
} 
Table 1.-Estimated number of water wells drilled in the United States, by State

[Based mainly on data supplied by the U.S. Geol. Survey and State water agencies. Modified in part by other data available to the authors. NC, no change]

\begin{tabular}{|c|c|c|c|}
\hline \multirow{2}{*}{ State } & \multicolumn{2}{|c|}{ Estimated number of wells drilled } & \multirow{2}{*}{$\begin{array}{c}\text { Percent change } \\
1960-64\end{array}$} \\
\hline & 1960 & 1964 & \\
\hline Alabama...... & 4,000 & 4,500 & +13 \\
\hline Alaska & 726 & 1,001 & +38 \\
\hline Arizona & 1,400 & 1,520 & +9 \\
\hline Arkansas .... & 5,000 & 5,000 & NC \\
\hline California ... & 9,100 & 10,000 & +9 \\
\hline Colorado .... & 3,105 & 5,911 & +55 \\
\hline Connecticut .. & 6,500 & 6,500 & NC \\
\hline Delaware .... & 3,797 & 3,440 & -9 \\
\hline District of Columbia & 12 & 12 & NC \\
\hline Florida....... & 33,900 & 55,000 & +62 \\
\hline Georgia ..... & 10,500 & 10,000 & -5 \\
\hline Hawaii .... & 17 & 21 & +24 \\
\hline Idaho...... & 1,400 & 1,400 & $\mathrm{NC}$ \\
\hline Illinois.... & 21,000 & 19,500 & -7 \\
\hline Indiana $\ldots . .$. & 17,700 & 15,000 & -12 \\
\hline Iowa $\ldots \ldots$ & 9,000 & 15,000 & +66 \\
\hline Kansas ..... & 4,700 & 5,500 & +17 \\
\hline Kentucky .... & 9,880 & 9,620 & -3 \\
\hline - & 974 & 2,620 & +169 \\
\hline Maine ........ & 1,500 & 1,700 & +13 \\
\hline Maryland ... & 4,022 & 6,902 & +72 \\
\hline Massachusetts & 8,000 & 9,000 & +13 \\
\hline -...-. & 25,000 & 25,000 & $\mathrm{NC}$ \\
\hline - & 13,000 & 9,000 & -31 \\
\hline 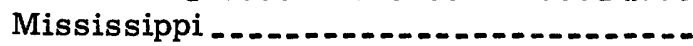 & 5,300 & 5,900 & +11 \\
\hline - & 0,380 & 9,990 & +57 \\
\hline 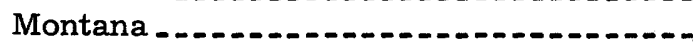 & 1,900 & 2,000 & +5 \\
\hline - & 5,511 & 6,005 & +9 \\
\hline Nevada .... & 824 & 825 & $\mathrm{NC}$ \\
\hline New Hampshire .. & 3,600 & 4,400 & +22 \\
\hline New Jersey .. & 3,797 & 3,440 & -9 \\
\hline New Mexico. & 2,287 & 3,150 & +41 \\
\hline New York .. & 25,000 & 25,000 & NC \\
\hline North Carolina & 20,000 & 25,000 & +25 \\
\hline North Dakota & 4,200 & 3,760 & -10 \\
\hline 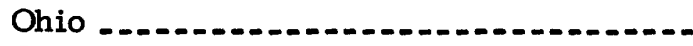 & 17,137 & 18,622 & +9 \\
\hline - - & 4,400 & 5,000 & +14 \\
\hline 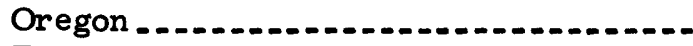 & 3,500 & 4,500 & +29 \\
\hline Pennsylvani & 13,482 & 16,220 & +20 \\
\hline Rhode Island ..... & 200 & 250 & +25 \\
\hline South Carolina .. & 5,300 & 5,400 & +2 \\
\hline South Dakota & 6,077 & 5,426 & -11 \\
\hline 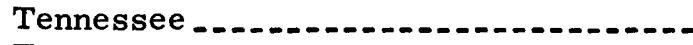 & 10,000 & 8,000 & -20 \\
\hline Texas & 19,000 & 25,000 & +32 \\
\hline Utah & 630 & 650 & +3 \\
\hline Vermont.......... & 1,240 & 1,460 & +18 \\
\hline Virginia & 8,500 & 10,000 & +18 \\
\hline Washington & 1,396 & 1,700 & +22 \\
\hline West Virginia & 5,500 & 5,900 & +7 \\
\hline n.m. & 11,000 & 12,000 & +9 \\
\hline Wyoming & 1,000 & 1,000 & NC \\
\hline
\end{tabular}


An estimated average cost per well of $\$ 1,500$, which seems reasonable but is merely a guess, indicates that national investment in water wells is about one-half to three-quarter billion dollars annually. These figures do not include the pump and plumbing segments of the industry. High-capacity irrigation, municipal, and industrial wells may cost 5 to 100 times the price of simply constructed moderate-yield domestic wells. Thus, the average value of a well in the West, where irrigation wells constitute a larger share of the total drilling effort, is higher than in the East, where domestic wells strongly predominate. However, the total dollar value of wells in the eastern half of the country may be greater inasmuch as it accounts for about 80 percent of all well drilling in the Nation.

Drilling activity in the $1960^{\circ} \mathrm{s}$, reported here, and estimates for the 1950's and earlier periods (Picton, 1956, 1959; Fiedler, 1957) show that the annual rate of drilling fluctuates but that the general trend is increased drilling from 1900 to the present. (See fig. 3.) The overall growth rate is 5,000 wells per year. In 1900 , about 155,000 wells were drilled, approximately one-third the number in 1964 . Major swings in well-construction activity relate to major events in American economy and history. The industry peaked during World War I, sagged during the following period of economic depression, recovered during the post-depression period as the accumulated backlog of well-drilling needs was erased and the value of irrigation with ground water was proved, accelerated following World War II, and peaked at about the start of the Korean war. It sagged again during and following that war, and as shown in figure 3, the industry currently is experiencing an upswing. Apparently the number of wells being drilled today (1966) equals or exceeds the highest peak period shown in figure 3.

Water-well trade jorunals have generally stated larger annual well-drilling totals for the Nation than those compiled by Federal Government agencies. The difference is explained in part by the exclusion in Government tallies, including the present one, of blast holes, tremies, foundation borings, test holes, and other holes not drilled specifically for construction of production water wells.

\section{NATIONAL TRENDS IN WELL DRILLING}

Intensity and distribution of water-well drilling are dependent on the vicissitudes of man and nature. As a general rule, it may be said that large numbers of wells are drilled where ground-water supplies are naturally abundant or adequate and that few wells are drilled where they are sparse. However, it does not necessarily follow that ground-water pumpage is heaviest where well density is greatest. In many parts of the Nation, the number of wells drilled may bear little relation to ground-water withdrawals because domestic supply wells constitute by far the greatest proportion of new wells, yet account for only a relatively small part of the withdrawals. Irrigation and industrial wells, though smaller in total number, are responsible for most of the ground-water withdrawal. Municipal and housing-development well fields, too, are characterized by large withdrawals from a moderate number of high-capacity wells.

Figure 3 indicates little net change in well drilling during the last 15 years, but groundwater withdrawals over the same period have increased appreciably. As knowledge of hydrology of the Nation's water resources expands and as competency in water-supply development and well technology increase, the trend seems to be toward a limited number of efficient wells located on the basis of technical knowledge of aquifer behavior rather than large batteries of wells as a means of increasing water supply. This trend is evident in Arizona, Nebraska, and some of the other States heavily tapped for ground water. A single modern irrigation well in Nebraska may yield as much water as 500 or more domestic or stock wells.

New rural and outer fringe suburban housing accounts for an appreciable share of the upward trend in well drilling throughout much of the country in the 1960 's. Centrally supplied municipal water systems are expanding into suburbs, but suburbs are expanding into the countryside. New irrigation and industrial wells in the South and West account for part of the increased drilling. Regional population shifts between 1960 and 1964 relate only vague ly to changes in drilling activity. Middecade census data show greatest gains in population in Southwestern and Southern States and in a few Middle and North Atlantic Coast States (U.S. Department of Commerce Census Bureau, 1966). Well drilling also increased in the South, but in only parts of the Southwest, and in nearly every State along the Atlantic coast (fig. 1).

Natural phenomena account for part of the recent increase, too. The current severe 
drought in the Northeastern and Middle Atlantic States has stimulated drilling, as did the 193237 drought in the Midwest. Ground-water reserves are depleted more slowly than streamflow and surface reservoirs during drought, but the multiyear drought in these regions has necessitated widespread construction of new wells. Following imposition of restrictions on public-supply water use on Long Island, N.Y., drilling of private wells to overcome the inconvenience of the water ban has increased several hundred percent over the normal rate. In Alaska, water-well replacement drilling jumped 28 percent following the Alaska earthquake of March 1964, which ruined many wells.

Nearly static agricultural economy, such as in the Northern Great Plains States, maturing or leveling of industrial development, extension of municipal distribution systems, and local favored development of surface water account for the small change or decrease in drilling activity experienced in some parts of the country in recent years.

For the Nation as a whole, the net change between 1960 and 1964 was an increase of 14 percent in drilling activity.

\section{REGIONAL TRENDS}

Grouping of contiguous States with similar trends in well-drilling activity (fig. 2, table 2) reveals substantial differences in water-well construction trends throughout the Nation.

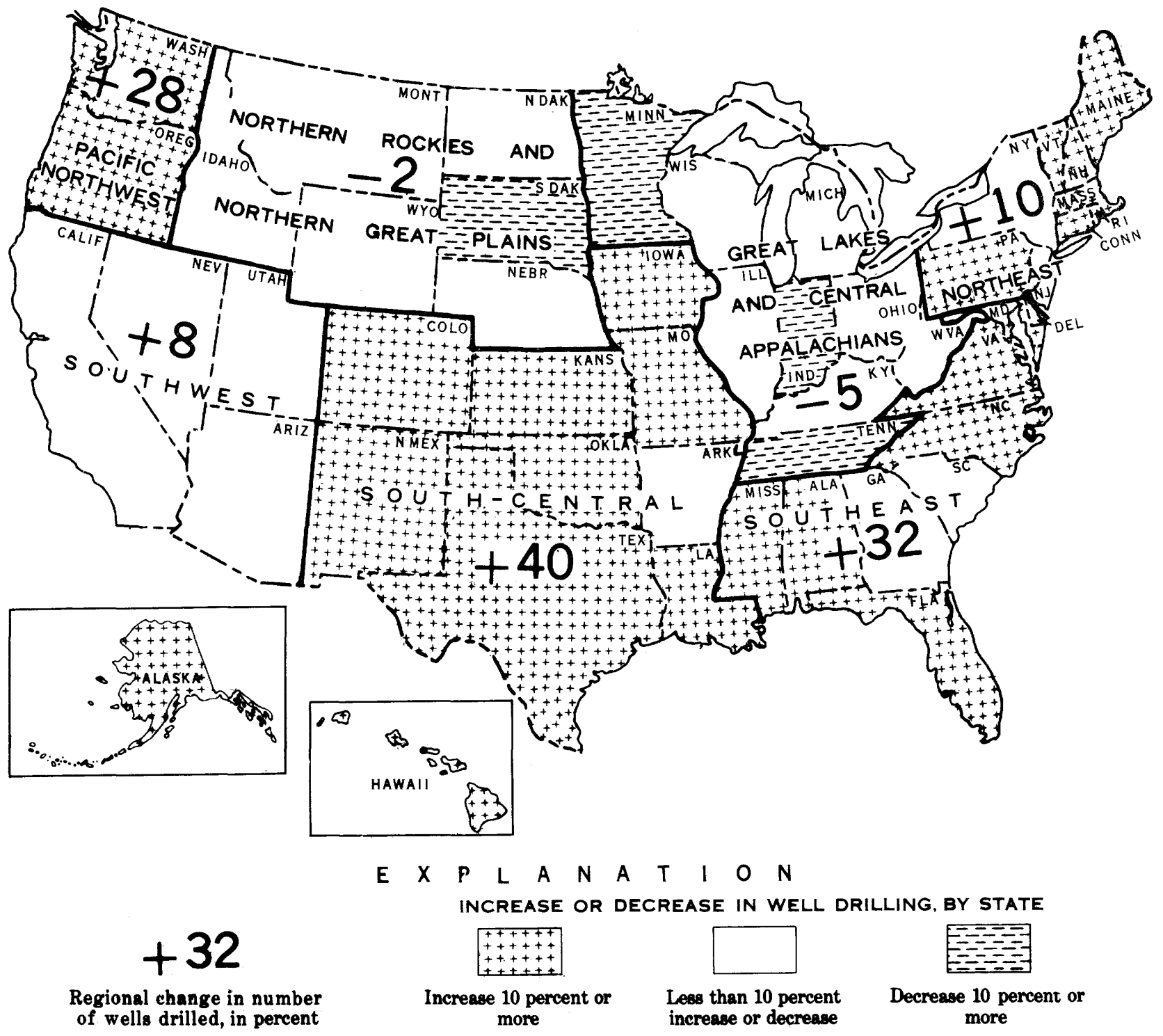

Figure 1. - Changes in well-drilling activity, 1960-64. 


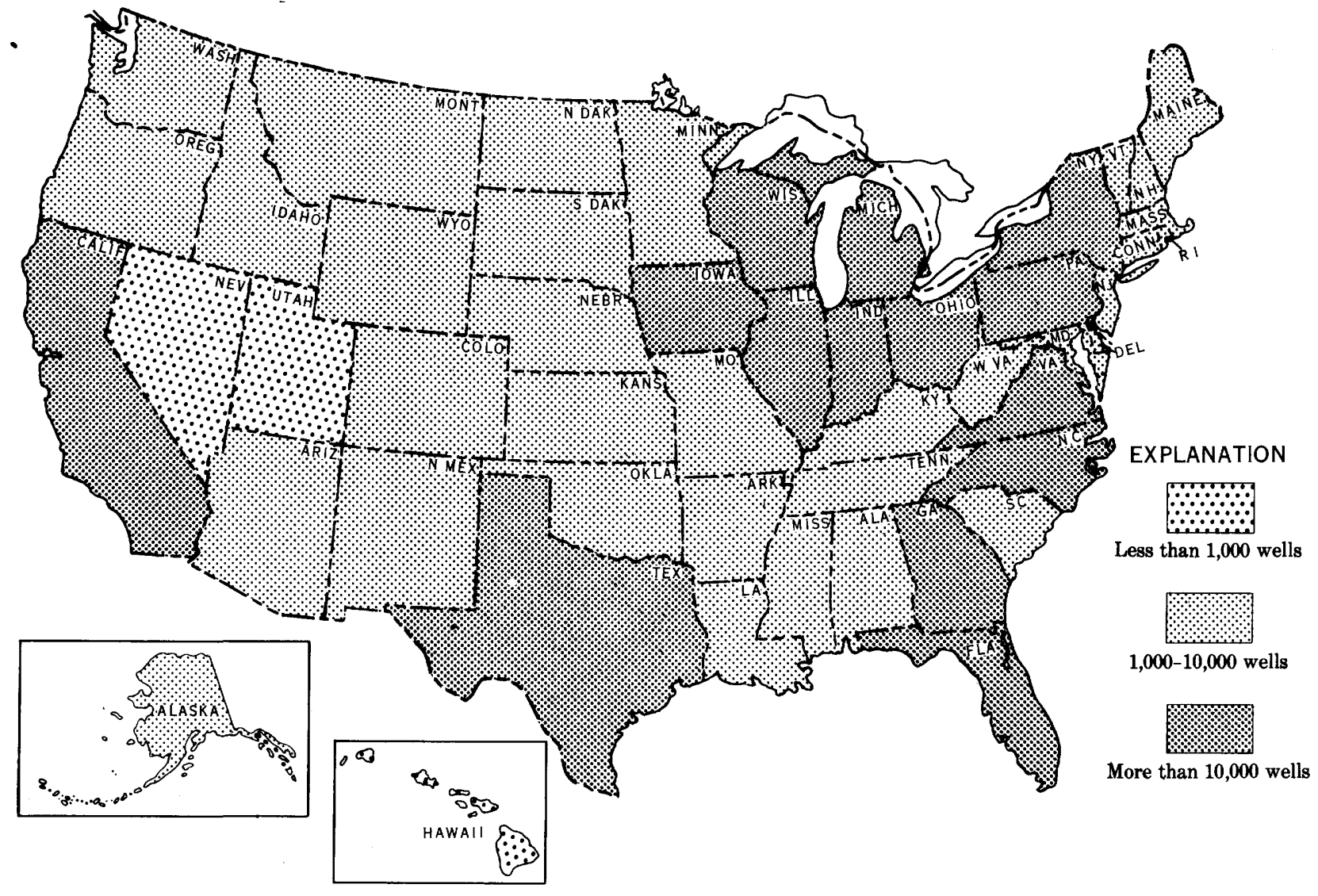

Figure 2. -Number of water wells drilled in 1964, by State.

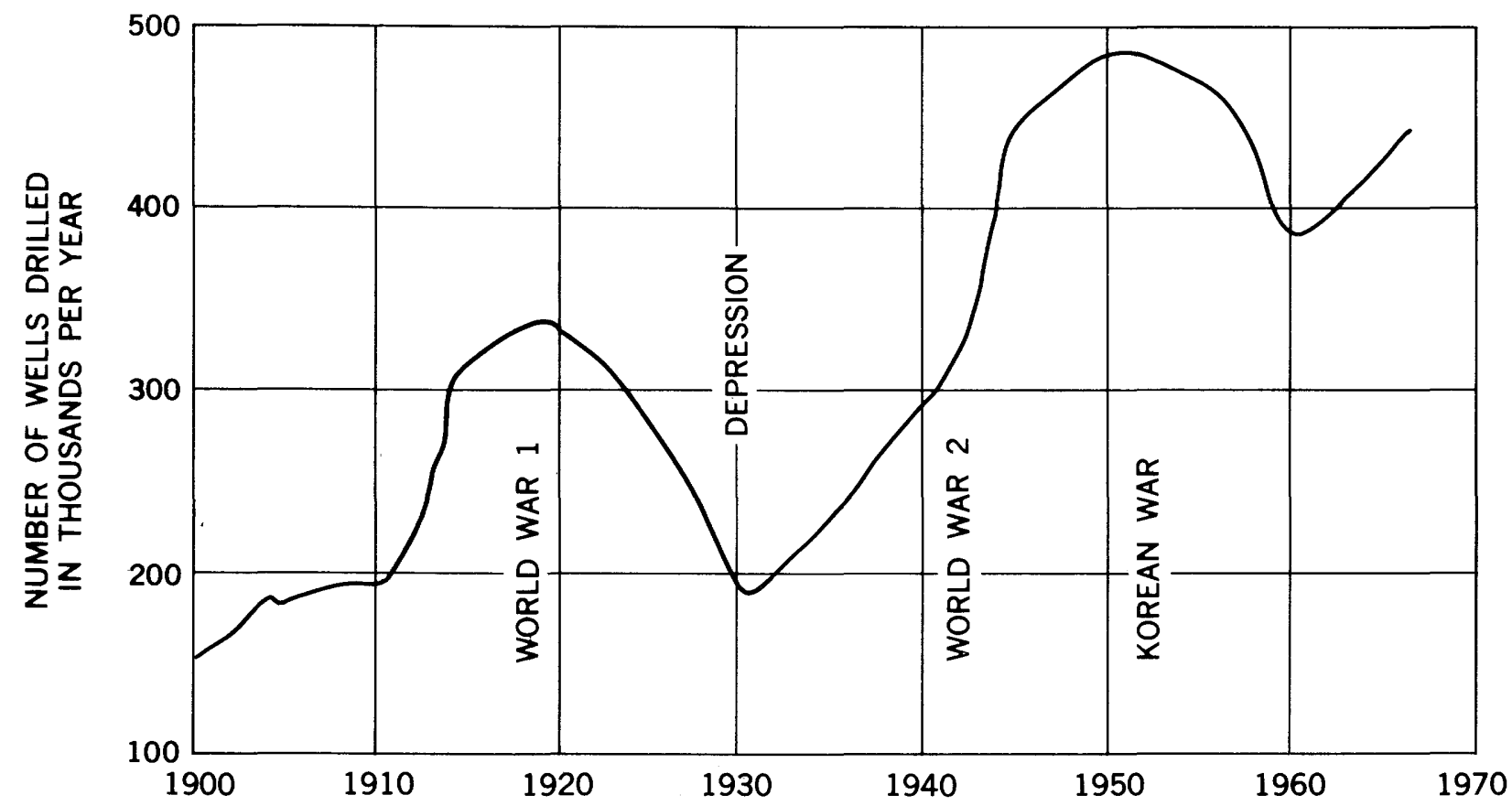

Figure 3.-Number of water wells drilled in the United States between 1900 and 1965 and relation to major events in American history. Graph adapted largely from Picton (1956). 
Table 2.-Regional trends in water-well construction in the United States, 1960-64

\begin{tabular}{|c|c|c|c|c|}
\hline Region & $\begin{array}{c}\text { Number of wells } \\
\text { drilled, } 1960\end{array}$ & $\begin{array}{c}\text { Number of wells } \\
\text { drilled, } 1964\end{array}$ & $\begin{array}{l}\text { Percent of total } \\
\text { drilled in } 1964\end{array}$ & $\begin{array}{c}\text { Percent change } \\
1960-64\end{array}$ \\
\hline South-central_ & 54,800 & 77,200 & 18 & +40 \\
\hline Southeast ...- & 95,300 & 126,100 & 28 & +32 \\
\hline Pacific Northwest (includes & & & & \\
\hline Alaska) & 5,600 & 7,200 & 2 & +28 \\
\hline Southwest (includes Hawaii) & 12,000 & 13,000 & 3 & +8 \\
\hline Northeast & 63,300 & 70,000 & 16 & +10 \\
\hline Northern Rockies and northern & & & & \\
\hline Great Plains & 20,100 & 19,600 & 5 & -2 \\
\hline Great Lakes and central & & & & \\
\hline Appalachians . . & 130,200 & 122,600 & 28 & -5 \\
\hline Totals. & 381,300 & 435,700 & 100 & $1+14$ \\
\hline
\end{tabular}

${ }^{1}$ Comparison of national totals.

Three regions exceeded the national increase of 14 percent. Major numerical and percentage increases in drilling are centered in the Southeast and South-central States. These two regions account for the bulk of the national increase in drilling, about 54,400 wells, between 1960 and 1964. In 1964, drilling exceeded 10,000 wells in five States in these regions (fig. 2). These are regions of growing irrigation-well use, industrial development, suburban sprawl, and rural population. The magnitude of drilling in these two southern regions is illustrated by the fact that in any recent year they have accounted for nearly half the Nation's total well construction. These regions include the Gulf and Atlantic Coastal Plains where the well replacement rate is higher than in other parts of the country owing to corrosion, encrustation, and screen or well pack failure. The high replacement rate stems from chemical characteristics and mineral constituents of the ground water and the complex well construction required by the unconsolidated multilayered materials of the Coast al Plains. Well life expectancy is especially short along parts of the gulf coast. In Louisiana, the drilling ratio of replacement wells to additional wells is $3: 1$, which apparently is the highest replacement rate in the country. In adjacent Mississippi, it is about 1:1. By contrast, the replacement rate in Colorado is only about 1 in each 100 wells drilled.

The Southeast region includes Florida, the State most intensively drilled in 1964, where approximately 55,000 wells were constructed as compared with the national average of
8,700 wells per State. Florida's economic and population boom and strong reliance on ground water are the reasons.

Regions bordering on the Great Lakes seem to be undergoing "peaking out" of well-drilling activity. Decline or leveling of drilling in States bordering the Great Lakes is attributed to widespread extension of municipal and suburban distribution systems that derive water from surface-water sources, in lieu of ground water that lies undeveloped underfoot in much of the region, and maturity of industrial development. The Great Lakes and central Appalachians region experienced a 5-percent decline between 1960 and 1964. The Northeast gained 10 percent, but this rise is explained by increases in drilling in New England At lantic Coast States distant from the Great Lakes. These States are enjoying a moderate industrial revival and new recreational and tourist economic stimulus. New York, the only State in the Northeast region bordering on the Great Lakes (except for a small part of Pennsylvania), experienced virtually no net change in drilling during the 5-year period. In the central Appalachians, retardation of drilling activity relates to loss of population, reduction in farming, and the readjustments of the economy now underway.

However, despite these influences, the Great Lakes and central Appalachians region and the Northeast region together still constitute an important slice of the well-drilling industry; they account for 44 percent of all wells drilled 
in the country in 1964. The Great Lakes are virtually ringed on the American side with States in which drilling exceeds 10,000 wells a year (fig. 2).

In terms of the number of wells drilled, regions of the far West account for less than 5 percent of the total national industry. In the Pacific Northwest, an area of current industrial growth, drilling increased 28 percent during 1960-64; but for the year 1964, it was only 2 percent of the national total. For convenience, Alaska is included in this region. Alaska's population increased greatly in the last five years, and including a 28-percent boost in drilling caused by the destructive Alaska earthquake of March 1964, well drilling rose 38 percent during 1960-64.

The Southwest accounted for less than 3 percent of the national total drilling in 1964 , despite the fact that every State in the region (Hawaii is included) experienced a population gain considerably above the national average in the first half of this decade. California is the only State west of the Rockies in which drilling in 1964 totaled as much as 10,000 wells. Apparently the California advance of about 10 percent in drilling during the period covered by this tally resulted from suburban expansion, industrial growth, and a moderate increase in irrigation-well construction; but the data are in need of refinement. Other significant factors are replacements stemming from well failure due to corrosion, faulty construction, or damage to wells from land subsidence.

Hawaii is the only State in the Southwest well-drilling region in which drilling advanced more than 10 percent during 1960-64.

The Northern Rocky Mountains and northern Great Plains constitute a well-drilling region of moderate activity in which, according to available data, drilling declined about 2 percent between 1960 and 1964. The Rockies remain thinly populated with little agriculture or industry, and the northern Great Plains is a region of mature and stable agricultural development with little or no change in production in the 5-year period covered by the tally.

\section{SUMMARY}

Growth trends of the well-drilling industry and numerical well counts, when analyzed by regions, relate in varying degrees to patterns and intensity of development of the Nation's ground-water resources. These trends indicate the following:

1. Ground-water pumpage is increasing about 4 percent (about $2 \mathrm{bgd}$ ) each year. As the use of ground water increases, the activity in well drilling increases, but at a slower proportional rate because of increased hydrologic knowledge and technical capability for locating and developing ground-water supplies.

2. The well-drilling industry totals about one-half to three-quarter billion dollars annually. The overall industry is presently experiencing a sharp upswing indrilling activity, but activity varies from region to region.

3. Grouping of States by increase or decrease in drilling activity delineates welldrilling regions whose boundaries are determined by regional changes in economy and development, population growth and shifts, changes in irrigation practice, and even natural phenomena such as earthquakes and drought.

Study of the data indicates that the above changes account in large measure for drilling trends. The study also raises many questions related to their significance. Are the regions now experiencing uptrends in drilling the ones that warrant greatest planning effort? Are these the ground-water problem areas of the future? Are areal ground-water investigations and well technology in tune with water-well needs of the future? Knowledge of the groundwater resources of the Nation is advancing and is enabling improvement in scientific methods of ground-water development. These advances, coupled with improvements in well technology, are permitting greater withdrawals of water from fewer wells.

The high replacement rate and the impact of drought on well supplies in some parts of the country indicate a need for additional technologic research directed toward better, but nevertheless moderately priced, materials and well design and toward greater compatibility of well materials and well design with the environment of the wells.

\section{REFERENCES CITED}

Ackerman, E. A., and others, 1960, Water resources activities in the United States-the impact of new techniques on integrated multiple-purpose water development: U.S. 86th 
Cong., 2d sess., Senate Select Comm. Natl. Water Resources, Comm. Print 31, 97 p. Fiedler, A. G., 1957, Importance of ground water in our national economy: Proc. Amer. Soc. Civil Engineers, Jour. Sanitary Engineering Div., v. 83, no. SA3, June 1957. McGuinness, C. L., 1963, The role of ground water in the national water situation: U.S. Geol. Survey Water-Supply Paper 1800, $1121 \mathrm{p}$.

MacKichan, K. A., 1951, Estimated use of water in the United States, 1950: U.S. Geol. Survey Circ. 115, 13 p.
MacKichan, K. A., and Kammerer, J. C., 1961, Estimated use of water in the United States, 1960 : U.S. Geol. Survey Circ. 456, 44 p.

Picton, Walter L., 1956, The water picture today-a national summary of ground water use and a projection to 1975: Water Well Journal, April 1956.

-1959, How many wells are we drilling? : Water Well Journal, June 1959.

U.S. Department of Commerce Census Bureau, 1966, Americans at Mid-Decade: Current Population Series, P23-16 Rept., 26 p. 